20 Amery A, Birkenhäger W, Brixko $\mathrm{P}$, et al. Mortality and morbidity results from the European working party on high blood pressure in the elderly trial. Lancet 1985; ;:1349-54.

21 Amery A, Birkenhäger W, Brixko P, et al. Efficacy of antihypertensive drug treatment according to age, sex, blood pressure and previous cardiovascular treatment according age, sex, blod press 686 ;ii:589-92.

22 Kahn HA. An introduction to epidemiologic methods. New York: Oxford University Press, 1983.

23 Amery A, De Schaepdryver A. (For the European Working Party on High Amery A, De Schaepdryver A. (For the European Working Party on High
blood pressure in the Elderly.) Antihypertensive therapy in patients above age sixty. In: Onesti G, Kim KE, eds. Hypertension in the young and old. New York: Grune and Stratton, 1981:315-26.

24 Bulpitt CJ, Beevers DG, Butler A, et al. Treated pressure rather than pretreatment predicts survival in hypertensive patients. A report from the DHSS hypertension care computing project (DHCCP). F Hypertens 1988;6: 627-32.

25 Kannel WB. Role of blood pressure in cardiovascular disease: the Framingham study. Angiology 1975;26:1-14.
26 Anderson TW. Re-examination of some of the Framingham blood pressure data. Lancet 1978;ii:1139-41.

27 Coope J, Warrender TS, McPherson K. The prognostic significance of blood pressure in the elderly. Fournal of Human Hypertension 1988;2:79-88.

28 Lindholm L, Lanke J, Bengtsson B, et al. Both high and low blood pressure risk indicators of death in middle-aged males. Isotonic regression of bured pres ince on pressure on age applied to data from a 13-year prospective study. Acta Med

29 Lindholm L, Lanke J, Bengtsson B. U-shaped association between mortality and blood pressure in a thirteen-year prospective study. Family Practice 1986;3:3-8.

30 Miall WE, Brennan PJ. Hypertension in the elderly: the south Wales study In: Onesti G, Kim KE, eds. Hypertension in the young and very old. New York: Grune and Stratton, 1981:227-83.

31 Anonymous. How far to lower blood pressure? [Editorial.] Lancet 1987;ii $251-2$.

(Accepted 5 April 1989)

\title{
Prevalence and diagnosis of chronic respiratory symptoms in adults
}

Peter Littlejohns, Shah Ebrahim, Ross Anderson

\begin{abstract}
Objective-To investigate the prevalence and diagnosis of chronic respiratory disease in adults.

Design-Screening questionnaire was sent to all patients aged 40-70 on the register of a group general practice; those responding positively were sent a detailed questionnaire and invited for assessment of respiratory function by forced expiratory volume in one second, forced vital capacity, peak flow rate, and reversibility studies with a $\beta$ adrenergic inhaler.
\end{abstract}

Setting-Group general practice in south west London.

Results-Of 2387 patients aged 40-70, 1444 completed a screening questionnaire. Of the 509 patients who reported cough, phlegm, wheeze, or shortness of breath, 324 responded to a detailed questionnaire, 256 of whom had simple respiratory function assessed. Chronic bronchitis affected $106(17 \%)$ men and $58(7 \%)$ women, and wheeze occurring at least once a week affected $60(9 \%)$ men and $20(3 \%)$ women. Only a half to a third of patients had received a diagnostic label of chronic bronchitis or asthma for their symptoms. There was considerable clinical and physiological similarity (including reversibility of the airways) between patients labelled as having asthma and having chronic bronchitis. A label of asthma was used more often for patients of social classes I and II.

Conclusions-Comparison with prevalence surveys carried out in the 1950 s showed that respiratory symptoms are as common now as then, but the risk of disabling chronic bronchitis has fallen, more among men than women, probably because of their reduced smoking. Changes in diagnostic fashion, together with increased detection, may have contributed to the upward trend in reported morbidity from asthma over the past 30 years.

Department of Clinical Epidemiology and Social Medicine, St George's Hospital Medical School, London SW17 0RE

Peter Littlejohns, MFCM, lecturer

Shah Ebrahim, DM, Wellcome Trust lecturer Ross Anderson, $\mathrm{MD}$, professor

Correspondence to: $\mathrm{Dr}$ Littlejohns.

BrMed f 1989;298:1556-60 diagnosis, management, and presentation of patients.

As asthma and chronic bronchitis in adults share some important symptomatic and pathophysiological features, diagnostic transfer may also contribute to these trends. It has been reported in studies from America, ${ }^{89}$ but its extent and implications have not been examined in the general population in the United Kingdom. We investigated the prevalence of chronic respiratory symptoms and their associated diagnostic labels and medical care in a general adult population and examined the extent to which illnesses labelled as asthma or chronic bronchitis differed in their clinical and physiological features and what other factors were associated with the acquisition of these labels. We also compared their prevalences with those found in similar studies that were carried out in the $1950 \mathrm{~s} .{ }^{10-14}$

\section{Methods}

The age-sex register of a group general practice in south west London was used to identify men and women aged 40-70. They were sent a previously validated screening questionnaire that inquired about coughing on winter mornings, phlegm on winter mornings, wheezing or whistling in the chest, shortness of breath on washing and dressing, and distance walked on the level before becoming short of breath.' $\mathrm{Up}$ to two reminders were sent. Patients who responded positively to at least one question were sent a detailed respiratory questionnaire that included questions on chronic bronchitis from the Medical Research Council's respiratory questionnaire. ${ }^{16}$ Questions were also asked about the frequency and duration of symptoms over the past year; walking capability on the level, on hills, and on stairs; and the effect of the respiratory illness on everyday life and activities. Subjects were asked to record what they considered to be the diagnosis of their condition. The diagnosis recorded in the general practitioner's case notes was also obtained.

All subjects who completed the detailed questionnaire were invited to the surgery for tests of respiratory function. Forced expiratory volume in one second, forced vital capacity, and peak expiratory flow rate were measured with a McDermott spirometer, which was calibrated daily; the best of five attempts was recorded. Height was measured to the nearest centimetre. Reversibility with a $\beta$ adrenergic inhaler was assessed 10 minutes after inhalation of $1 \mathrm{mg}$ of terbutaline (four puffs) from a Nebuhaler (Astra 
Pharmaceuticals). Predicted values for lung function were calculated with the regression equations of Cotes. ${ }^{17}$

The prevalence of the symptoms on the screening questionnaire was calculated by using as a denominator the number of responses to the questionnaire. The prevalence of symptoms on the detailed questionnaire was calculated using the same denominator after adjusting for the response to the questionnaire, and the $95 \%$ confidence intervals for prevalence were calculated using the actual number of respondents.

Subjects were assigned to social class groups according to the registrar general's classification, ${ }^{18}$ married women being classified according to their husband's occupation and retired people by their main lifetime occupation. When numbers were small social classes I and II were combined, as were IV and V. When social class was incorporated into a multiple logistic regression model it was dichotomised into social classes I and II and classes III, IV, and V.

Reliability of the detailed questionnaire was assessed by having a subgroup of subjects complete the questionnaire again three weeks later. Repeatability of questions was analysed by the kappa statistic. Further validation of the screening questionnaire was undertaken by inviting a random sample of subjects who had responded negatively to all screening questions to complete a detailed questionnaire and have their respiratory function assessed.

All analyses were carried out with the statistical package for the social sciences (SPSSX) on the University of London's Amdahl computer. The $\chi^{2}$ test was used for comparing categorical data, and Student's $t$ test was used for normally distributed data. To examine the factors associated with various disease labels multiple logistic regression was used and the effects expressed as odds ratios together with their respective $95 \%$ confidence intervals.

\section{Results}

The screening questionnaire was sent to all 2387 eligible patients on the age-sex register. A total of 690 questionnaires were returned uncompleted because the person had moved away or died, giving an effective sample of 1697 ( 758 men and 939 women). In all, 1444 adequately completed questionnaires were returned, giving a response rate of $85 \%$. A total of 509 people responded positively to at least one of the screening questions and were therefore sent a detailed questionnaire. Of the $324(64 \%)$ who returned completed questionnaires, $256(79 \%)$ were seen at the surgery and had spirometry performed. There was no difference in response rates between men and women. The mean age of those who responded positively to the screening questionnaire was $58 \cdot 8$ years (SD 9.1) for men and $57 \cdot 6$ years $(9 \cdot 1)$ for women; $285(56 \%)$ who responded were men. Those who responded negatively to all questions were slightly younger (men $54 \cdot 0$ years; women $55 \cdot 5$ ) and $365(39 \%)$ were men. Those completing the detailed questionnaires and having spirometry had
TABLE II - Prevalence (\%) of chronic bronchitis diagnosed by various criteria, associated levels of disability and handicap, and prevalence of diagnosis of chronic bronchitis. Prevalence adjusted for response rate to questionnaire; adjusted numbers are given in parentheses

\begin{tabular}{|c|c|c|}
\hline & $\underset{(n=635)}{\text { Men }}$ & $\begin{array}{c}\text { Women } \\
(\mathrm{n}=809)\end{array}$ \\
\hline MRC definition ${ }^{\star}$ & $16 \cdot 7(106)$ & $7 \cdot 1(58)$ \\
\hline $95 \%$ Confidence interval of $\%$ & $14 \cdot 5$ to 18.9 & 3.7 to 10.5 \\
\hline Plus measure of disability $t$ & $5 \cdot 4(34)$ & $2 \cdot 9(23)$ \\
\hline $95 \%$ Confidence interval of $\%$ & $2 \cdot 8$ to $8 \cdot 0$ & 0.7 to $5 \cdot 1$ \\
\hline \multicolumn{3}{|l|}{$M R C$ definition plus measure of } \\
\hline handicap $\ddagger$ & $4 \cdot 7(30)$ & $3 \cdot 3(27)$ \\
\hline $95 \%$ Confidence interval of $\%$ & $2 \cdot 2$ to $7 \cdot 2$ & 1.0 to 5.6 \\
\hline Definition used in 1961 national study $\$$ & $4 \cdot 6(29)$ & $2 \cdot 5(20)$ \\
\hline $95 \%$ Confidence interval of $\%$ & $2 \cdot 1$ to $7 \cdot 0$ & 0.5 to 4.5 \\
\hline \multicolumn{3}{|l|}{ Diagnosis of chronic bronchitis } \\
\hline $\begin{array}{l}\text { reported by patient } \\
95 \% \text { Confidence interval of } \%\end{array}$ & $3.9(25)$ & $2 \cdot 1(17)$ \\
\hline $95 \%$ Confidence interval of $\%$ & $1 \cdot 6$ to $6 \cdot 1$ & 0.2 to 4.0 \\
\hline
\end{tabular}

${ }^{\star}$ Cough and phlegm for three months of the year for two successive years. ${ }^{16}$

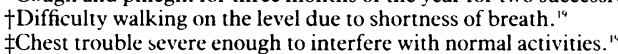

\#Chest trouble severe enough to interfere with normal activities.
jWinter cough and phlegm, episodes of cough and phlegm lasting for at least three weeks, and shortness of breath walking on the level."

similar distributions for sex, age, and symptoms to all those who had been sent the detailed questionnaire.

Of the 509 subjects who answered at least one of the screening questions positively, 134 (9\% of those who completed the screening questionnaire) reported wheeze alone; $128(9 \%)$ reported cough, phlegm, and wheeze; $99(7 \%)$ reported cough and phlegm; $92(6 \%)$ reported cough, phlegm, wheeze, and shortness of breath on washing and dressing; $37(3 \%)$ reported wheeze and shortness of breath; and $19(1 \%)$ reported shortness of breath alone, whereas $935(65 \%)$ answered negatively to all screening questions.

Table I shows age specific prevalences for chronic respiratory symptoms in the previous year. The most prevalent symptom was wheeze, which was reported by $75(34 \%)$ men and $69(21 \%)$ women aged $60-70$. Cough on winter mornings and phlegm on winter mornings were similar in prevalence in all age groups. The least frequent symptom was shortness of breath after walking less than 100 yards $(91 \mathrm{~m})$ on the level. All symptoms increased with age, though this trend was not significant for shortness of breath in men and cough in women.

\section{CHRONIC BRONCHITIS}

Table II shows the prevalence of chronic bronchitis according to the Medical Research Council and other definitions and as defined by the patient. When prevalence was adjusted for response rate $17 \%$ of men and $7 \%$ of women satisfied the Medical Research Council criteria for chronic bronchitis (106/635 men and 58/809 women). Of these, 31 (19\%) attributed their symptoms to smoking but gave no diagnosis, and $27(16 \%)$ considered that they had chronic bronchitis (with or without emphysema), 18 (11\%) asthma, 16 $(10 \%)$ acute bronchitis, $13(8 \%)$ heart disease, and 20 $(12 \%)$ some other disorder; $16(10 \%)$ said that there was nothing wrong with their chest, and $23(14 \%)$ said that they did not know what was wrong. No patients attributed their symptoms to chronic obstructive air-

TABLE I - Prevalence (\%) of respiratory symptoms in past year reported on screening questionnaire $(n=1444)$. Actual numbers reporting symptoms are given in parentheses

\begin{tabular}{|c|c|c|c|c|c|c|}
\hline & \multicolumn{3}{|c|}{ Men } & \multicolumn{3}{|c|}{ Women } \\
\hline & $\begin{array}{c}\text { Aged } 40-49 \\
(\mathrm{n}=227)\end{array}$ & $\begin{array}{c}\text { Aged } 50-59 \\
(n=187)\end{array}$ & $\begin{array}{c}\text { Aged } 60-70 \\
(\mathrm{n}=221)\end{array}$ & $\begin{array}{c}\text { Aged } 40-49 \\
(n=246)\end{array}$ & $\begin{array}{c}\text { Aged 50-59 } \\
(\mathrm{n}=236)\end{array}$ & $\begin{array}{c}\text { Aged } 60-69 \\
(n=327)\end{array}$ \\
\hline Cough on winter mornings & $16 \cdot 7(38)$ & $24 \cdot 0(45)$ & $27 \cdot 2(60)$ & $10 \cdot 1(25)$ & $14 \cdot 8(35)$ & $12 \cdot 8(42)$ \\
\hline $95 \%$ Confidence interval of $\%$ & $11 \cdot 8$ to $21 \cdot 6$ & $17 \cdot 8$ to $30 \cdot 2$ & $21 \cdot 3$ to $33 \cdot 1$ & $6 \cdot 3$ to $13 \cdot 9$ & $10 \cdot 2$ to $19 \cdot 4$ & $9 \cdot 2$ to $16 \cdot 4$ \\
\hline Phlegm on winter mornings & $14 \cdot 5(33)$ & $21 \cdot 9(41)$ & $27 \cdot 2(60)$ & $8 \cdot 9(22)$ & $7 \cdot 6(18)$ & $14 \cdot 6(48)$ \\
\hline $95 \%$ Confidence interval of $\%$ & $9 \cdot 9$ to $19 \cdot 1$ & 15.9 to 27.9 & $21 \cdot 3$ to $33 \cdot 1$ & $5 \cdot 3$ to $12 \cdot 5$ & $4 \cdot 2$ to $11 \cdot 0$ & $10 \cdot 7$ to $18 \cdot 5$ \\
\hline Wheeze & $22 \cdot 0(50)$ & $32 \cdot 6(61)$ & $33.9(75)$ & $14 \cdot 2(35)$ & $16 \cdot 9(40)$ & $21 \cdot 1(69)$ \\
\hline $95 \%$ Confidence interval of $\%$ & $16 \cdot 6$ to $27 \cdot 4$ & $25 \cdot 8$ to $39 \cdot 4$ & $27 \cdot 6$ to $40 \cdot 2$ & $9 \cdot 8$ to $18 \cdot 6$ & $12 \cdot 1$ to $21 \cdot 7$ & $16 \cdot 6$ to $25 \cdot 6$ \\
\hline Shortness of breath on walking 100 yards $(91 \mathrm{~m})$ & $1 \cdot 7(4)$ & $5 \cdot 3(10)$ & $4 \cdot 7(10)$ & $1 \cdot 2(3)$ & $2 \cdot 5(6)$ & $5 \cdot 2(17)$ \\
\hline $95 \%$ Confidence interval of $\%$ & $0 \cdot 0$ to $3 \cdot 4$ & $2 \cdot 1$ to $8 \cdot 5$ & 1.9 to 7.5 & 0.0 to 2.5 & 0.5 to 4.5 & $2 \cdot 8$ to $7 \cdot 6$ \\
\hline
\end{tabular}


ways disease or similar diagnoses. A total of 26 (16\%) had a diagnosis of chronic bronchitis recorded in their notes. Between a half and a third in the various age groups had an associated degree of disability (namely, shortness of breath leading to difficulty in walking) or handicap (shortness of breath leading to limitation of normal activities).

Table III shows the effects (as odds ratios) of sociodemographic factors, smoking, types of symptom, and use of health services on acquiring the label of having chronic bronchitis among patients who satisfied Medical Research Council criteria. Age, sex, social class, and smoking had no significant effect. The odds ratio of self reporting a label of chronic bronchitis was increased in association with all symptom and disability factors but was significant for only wheezing and phlegm. The frequency of attending the general practitioner or outpatient department increased the odds ratio slightly but not significantly.

\section{WHEEZING AND ASTHMA}

Table IV shows the prevalence of wheezing and associated morbidity. In all, 171 (27\%) men and 142 $(18 \%)$ women reported wheezing in the past year, and $60(9 \%)$ men and $20(3 \%)$ women reported wheezing at least once a week. Of this more severe group, 17 (21\%) reported that they had asthma, 18 (23\%) chronic bronchitis (with or without emphysema), $12(15 \%)$ acute bronchitis, $12(15 \%)$ heart disease, and $11(14 \%)$ some other problem; five $(6 \%)$ did not know the diagnosis, and five $(6 \%)$ said there was nothing wrong with their chest. No patients attributed their symptoms to chronic obstructive airways disease or similar diagnoses. Almost half $(18 / 37 ; 49 \%)$ of the patients who had attributed their wheezing to asthma had a diagnosis of asthma recorded in their case notes. Of 31 patients who had a diagnosis of asthma recorded in their notes, $20(65 \%)$ reported asthma as the cause of their symptoms.

Table III shows the relation of various factors to the

TABLE III-Relative odds that patients who satisfy MRC criteria would be labelled as having chronic bronchitis and that patients who wheeze would be labelled as having asthma

\begin{tabular}{|c|c|c|}
\hline & $\begin{array}{l}\text { Odds ratio }(95 \% \\
\text { confidence } \\
\text { interval) for } \\
\text { label of } \\
\text { chronic } \\
\text { bronchitis } \\
(\mathrm{n}=105)\end{array}$ & $\begin{array}{c}\text { Odds ratio }(95 \% \\
\text { confidence } \\
\text { interval) for } \\
\text { label of } \\
\text { asthma } \\
(n=201)\end{array}$ \\
\hline \multicolumn{3}{|l|}{ Sociodemographic factors: } \\
\hline $\begin{array}{l}\text { Age } \\
\quad(<55 v \geqslant 55)\end{array}$ & $\begin{array}{c}0.2 \\
(0.01 \text { to } 1.2)\end{array}$ & $\begin{array}{c}1 \cdot 7 \\
(0.7 \text { to } 3 \cdot 8)\end{array}$ \\
\hline $\begin{array}{l}\text { Sex } \\
\quad(\text { male } v \text { female })\end{array}$ & $\begin{array}{c}0.7 \\
(0.5 \text { to } 1.5)\end{array}$ & $\begin{array}{c}0.9 \\
(0.5 \text { to } 1.9)\end{array}$ \\
\hline $\begin{array}{l}\text { Social class } \\
(\mathrm{I}+\mathrm{II} v \mathrm{III}+\mathrm{IV}+\mathrm{V})\end{array}$ & $\begin{array}{c}1 \cdot 0 \\
(0 \cdot 3 \text { to } 4 \cdot 0)\end{array}$ & $\begin{array}{c}3 \cdot 8^{\star} \\
(1 \cdot 6 \text { to } 8 \cdot 7)\end{array}$ \\
\hline $\begin{array}{l}\text { Smoking state } \\
\quad \text { (non-smokers } v \text { smokers) }\end{array}$ & $\begin{array}{c}1.5 \\
(0.5 \text { to } 4.0)\end{array}$ & $\begin{array}{c}3 \cdot 1 \star \\
(1 \cdot 2 \text { to } 2 \cdot 6)\end{array}$ \\
\hline \multicolumn{3}{|l|}{ Symptoms: } \\
\hline $\begin{array}{l}\text { Cough } \\
\quad(\geqslant \text { once a week } v<\text { once a week })\end{array}$ & $\begin{array}{c}2 \cdot 0 \\
(0 \cdot 2 \text { to } 16 \cdot 8)\end{array}$ & $\begin{array}{c}0.8 \\
(0.4 \text { to } 1.8)\end{array}$ \\
\hline $\begin{array}{l}\text { Phlegm } \\
\qquad(\geqslant \text { once a week } v<\text { once a week })\end{array}$ & 0 & $\begin{array}{c}0.9 \\
(0.4 \text { to } 2.0)\end{array}$ \\
\hline $\begin{array}{l}\text { Wheeze } \\
(\geqslant \text { once a week } v<\text { once a week })\end{array}$ & $\begin{array}{c}6 \cdot 2^{\star} \\
(1 \cdot 6 \text { to } 24 \cdot 5)\end{array}$ & $\begin{array}{c}1 \cdot 3 \\
(0 \cdot 6 \text { to } 3 \cdot 1)\end{array}$ \\
\hline $\begin{array}{l}\text { Shortness of breath } \\
\quad(\geqslant \text { once a week } v<\text { once a week })\end{array}$ & $\begin{array}{c}2 \cdot 4 \\
(0 \cdot 6 \text { to } 9 \cdot 6)\end{array}$ & $\begin{array}{c}1 \cdot 2 \\
(0 \cdot 6 \text { to } 2 \cdot 5)\end{array}$ \\
\hline $\begin{array}{l}\text { Disability } \\
\text { (difficulty with walking on the level } \\
\text { due to shortness of breath) }\end{array}$ & $3 \cdot 3$ & 0.8 \\
\hline $\begin{array}{l}\text { Handicap } \\
\text { (chest trouble severe enough to affect }\end{array}$ & $\begin{array}{c}1.7 \\
1.7\end{array}$ & $\begin{array}{l}0 \cdot 3 \text { to } 1 \cdot 5) \\
2 \cdot 7^{\star}\end{array}$ \\
\hline $\begin{array}{l}\text { (chest trouble severe enough to affect } \\
\text { normal activities) }\end{array}$ & $(0.6$ to $5 \cdot 2)$ & $(1 \cdot 3$ to $5 \cdot 7)$ \\
\hline \multicolumn{3}{|l|}{$\begin{array}{l}\text { Utilisation of health services in } \\
\text { preceding year: }\end{array}$} \\
\hline $\begin{array}{l}\text { Attendance at general practitioner } \\
\text { (>once } v \text { once) }\end{array}$ & $\begin{array}{c}4 \cdot 4 \\
(0 \cdot 6 \text { to } 40 \cdot 9)\end{array}$ & $\begin{array}{c}0 \cdot 8 \\
(0 \cdot 3 \text { to } 2 \cdot 2)\end{array}$ \\
\hline Attendance at outpatient department & $\begin{array}{c}2.0 \\
(0.6 \text { to } 6.5)\end{array}$ & $\begin{array}{c}1 \cdot 3 \\
(0 \cdot 3 \text { to } 3 \cdot 3)\end{array}$ \\
\hline Admission to hospital & $\begin{array}{c}1 \cdot 0 \\
(0 \cdot 1 \text { to } 9 \cdot 0)\end{array}$ & $\begin{array}{c}0 \cdot 7 \\
(0 \cdot 5 \text { to } 2 \cdot 3)\end{array}$ \\
\hline
\end{tabular}

${ }^{\star p}<0.05$.
TABLE IV-Prevalence (\%) of severe and moderate wheezing in the preceding year and associated levels of morbidity and the presence of an asthmatic label. Prevalence adjusted for response rate to questionnaire; adjusted numbers are given in parentheses

\begin{tabular}{|c|c|c|}
\hline & $\underset{(n=635)}{\text { Men }}$ & $\begin{array}{c}\text { Women } \\
(\mathrm{n}=809)\end{array}$ \\
\hline Severe wheeze ${ }^{\star}$ & $9 \cdot 3(59)$ & $2 \cdot 5(20)$ \\
\hline $95 \%$ Confidence interval for $\%$ & $6 \cdot 0$ to $12 \cdot 8$ & 0.5 to 4.5 \\
\hline Severe wheeze and disabilityt & $5 \cdot 4(34)$ & $1.5(12)$ \\
\hline $95 \%$ Confidence interval for $\%$ & $2 \cdot 8$ to 8.0 & 0.0 to $3 \cdot 1$ \\
\hline Severe wheeze and handicap $\ddagger$ & $3 \cdot 7(23)$ & $1 \cdot 2(8)$ \\
\hline $95 \%$ Confidence interval for $\%$ & 1.5 to 5.9 & 0.0 to 2.6 \\
\hline Moderate wheeze $₫$ & $18 \cdot 0(114)$ & $15 \cdot 0(121)$ \\
\hline $95 \%$ Confidence interval for $\%$ & $13 \cdot 5$ to $22 \cdot 5$ & $10 \cdot 3$ to $19 \cdot 7$ \\
\hline Moderate wheeze and disability $\dagger$ & $5 \cdot 9(37)$ & $5 \cdot 6(45)$ \\
\hline $95 \%$ Confidence interval for $\%$ & $3 \cdot 2$ to $8 \cdot 6$ & $2 \cdot 6$ to 8.6 \\
\hline Moderate wheeze and handicap $\ddagger$ & $5 \cdot 7(36)$ & $7 \cdot 1(57)$ \\
\hline $95 \%$ Confidence interval for $\%$ & 3.0 to $8 \cdot 1$ & $3 \cdot 7$ to $10 \cdot 5$ \\
\hline Diagnosis of asthma reported by patient & $4 \cdot 7(30)$ & $3 \cdot 3(27)$ \\
\hline $95 \%$ Confidence interval for $\%$ & $2 \cdot 2$ to $7 \cdot 2$ & 1.0 to 5.6 \\
\hline
\end{tabular}

«Wheeze at least once a week.

†Difficulty walking on the level due to shortness of breath. $\ddagger$ Interference with normal activities due to chest trouble. ¿Wheeze less than once a week.

TABLE $\mathrm{V}$-Characteristics of patients labelled as having asthma and chronic bronchitis ${ }^{\star}$

$\begin{array}{cc}\begin{array}{c}\text { No }(\%) \text { of } \\ \text { patients } \\ \text { labelled as } \\ \text { having asthma } \\ (\mathrm{n}=33)\end{array} & \begin{array}{c}\text { No }(\%) \text { of } \\ \text { patients } \\ \text { labelled as } \\ \text { having chronic } \\ \text { bronchitis } \\ (\mathrm{n}=23)\end{array} \quad \text { Significance }\end{array}$

Sociodemographic factors:

Age:

$40 \cdot 49$

$50-59$
$60-69$

60-69

Social class:
I and II

III, IV, and V

Smoking state:

Never smoked

Stopped smóking

Smoking

Symptoms:

Wheeze:

At least once a week

Less than once a week

Never

Cough:

At least once a week

Less than once a week

Never

Phlegm:

At least once a week

Less than once a week

Never

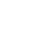

$(n=23)$

Significance

Shortness of breath:

At least once a week

Less than once a week

$11(33)$

$9(27)$
$13(40)$

0
$8(35) \quad \gamma^{2}=8 \cdot 44$,

$14(42) \quad 4(18) \quad \chi^{\prime}=2 \cdot 83$,

$\begin{array}{rll}4(18) & \chi=2 \cdot 83, \\ 19(58) & 19(82) & \mathrm{d} f=1, \mathrm{p}=0.1\end{array}$

$11(33)$

$13(40)$

$2(9)$

$\chi^{2}=6 \cdot 57$,

9 (27) $\quad$ 13(56) $\mathrm{df}=2, \mathrm{p}=0.04$

$8(24)$
$23(70)$

$23(70)$
$2(6)$

(3)

$\begin{aligned} 9(39) & \chi^{:}=4 \cdot 19, \\ 10(43) & \mathrm{df}=2, \mathrm{p}=0 \cdot 12 \\ 4(18) & \end{aligned}$

$15(45)$
$15(45)$

$15(45)$
$3(10)$

$\begin{aligned} 18(78) \\ 5(22)\end{aligned} \quad \gamma^{2}=6 \cdot 7$,

$\begin{array}{ll}5(22) & \gamma_{\mathrm{d}}=6 \cdot 7, \\ 0 & \mathrm{df}=2, \mathrm{p}=0.03\end{array}$

$19(58)$

$10(30)$

$17(74)$
$5(22)$

$\begin{array}{ll}5(22) & \chi_{\mathrm{d} f}=1.85, \\ 1(4) & \end{array}$

$\chi^{2}=1 \cdot 85$,

$13(40)$

$18(55)$

$9(40)$

$7(30)$
$7(30)$

$\chi^{2}=6 \cdot 77$,

$\mathrm{df}=2, \mathrm{p}=0.03$

No significant difference for sex, disability, handicap, general practitioner attendance, outpatient attendance, and inpatient episodes.

^Four patients with both diagnoses were excluded from the analysis.

acquisition of the label of having asthma in those who reported wheezing in the past year. The odds ratio was significantly increased with non-smoking state, higher social class, and the presence of respiratory handicap, but was not increased with age, sex, greater severity of symptoms, or use of medical services. The effect of social class remained significant $(\mathrm{p}<0.05)$ when smoking state was controlled for (odds ratio $3 \cdot 2,95 \%$ confidence interval $1 \cdot 4$ to $7 \cdot 3$ ), when severity of wheeze was controlled for (odds ratio $4 \cdot 1,95 \%$ confidence interval 1.8 to $9 \cdot 4$ ), and when patients labelled as having chronic bronchitis were excluded from the analysis (odds ratio 3.0,95\% confidence interval $1 \cdot 3$ to $7 \cdot 0$ ). Of patients who reported wheezing in the preceding year, $16(34 \%)$ of the 47 from social classes I and II had been labelled as having asthma compared with $17(12 \%)$ of the 137 from social classes III, IV, and $\mathrm{V}$.

Four patients reported diagnostic labels of both asthma and chronic bronchitis. Comparison of the patients labelled as having asthma and as having 
chronic bronchitis showed no significant differences in sex $(17 / 33(52 \%)$ and $14 / 23(61 \%)$, respectively, were men), severity of wheezing $(8 / 33(24 \%)$ and $9 / 23(39 \%)$ wheezed at least once a week), or production of phlegm $(19 / 33(58 \%)$ and $17 / 23(74 \%)$ produced phlegm at least once a week). Five (15\%) of those with asthma and five $(22 \%)$ of those with chronic bronchitis reported difficulty walking on the level most days, and 21 (64\%) and $14(61 \%)$ had attacks sufficiently severe to interfere with normal activities. Use of medical services was not significantly different between those labelled as having asthma and as having chronic bronchitis: $25(76 \%)$ and $15(65 \%)$, respectively, had consulted their general practitioner in the preceding year; eight $(24 \%)$ and seven (30\%) had been referred to an outpatient department; and three (9\%) and two (9\%) had been admitted. Those labelled as having asthma were younger, came from higher social classes, and reported less coughing and more frequent shortness of breath (table V).

\section{RESPIRATORY FUNCTION}

Table VI compares the lung function of patients labelled as having asthma with that of those labelled as having chronic bronchitis. Both groups had reductions of forced expiratory volume in one second, forced vital capacity, and persistent airflow obstruction, and the degree of reduction was not significant between groups. Bronchodilatation achieved with $\beta$ adrenergic inhaler was similar in both groups. Patients without a diagnostic label had less severe respiratory impairment and a smaller response to $\beta$ adrenergic inhaler.

\section{Discussion}

Using data from only one group practice means that the diagnostic labels given represent the views of a limited number of general practitioners, but as it was a London practice the migration of patients was considerable so that the labels had also been given by more doctors than those in the practice. The details of doctors' diagnoses were obtained retrospectively, thus avoiding the possible bias in many prospective studies based in general practice that use volunteer general practitioners. $^{20}$ We achieved a high response to the initial screening questionnaire, which allowed estimates of the degree of bias in response to the

TABLE VI - L ung function of patients with chronic respiratory symptoms who were labelled as having asthma or chronic bronchitis and those not labelled with a diagnosis

\begin{tabular}{lccc}
\hline & $\begin{array}{c}\text { Patients labelled } \\
\text { as having } \\
\text { asthma } \\
\text { (n=32) }\end{array}$ & $\begin{array}{c}\text { Patients labelled } \\
\text { as having } \\
\text { chronic } \\
\text { bronchitis } \\
\text { (n=19) }\end{array}$ & $\begin{array}{c}\text { Patients not } \\
\text { labelled with } \\
\text { a diagnosis } \\
\text { (n=176) }\end{array}$ \\
\hline \% Of predicted forced expiratory volume & 60 & 61 & 80 \\
95\% Confidence interval & 50 to 70 & 48 to 75 & 77 to 83 \\
\% Of predicted forced vital capacity & 79 & 73 & 89 \\
95\% Confidence interval & 69 to 89 & 63 to 84 & 86 to 92 \\
\% Of predicted peak flow & 57 & 55 & 76 \\
95\% Confidence interval & 47 to 67 & 41 to 70 & 73 to 79 \\
\% Change in peak flow in response to $\beta$ adrenergic inhaler & 20 & 17 & 4 \\
95\% Confidence interval & 7 to 32 & 3 to 31 & 2 to 6 \\
Forced expiratory volume as \% of forced vital capacity & 63 & 64 & 73 \\
95\% Confidence interval & 57 to 70 & 57 to 72 & 72 to 75 \\
\hline
\end{tabular}

TABLE VII - Prevalence (\%) of chronic respiratory symptoms in people aged 55-64 in 1950s and 1980s

\begin{tabular}{|c|c|c|c|c|c|c|c|c|}
\hline & \multicolumn{4}{|c|}{ Men } & \multicolumn{4}{|c|}{ Women } \\
\hline & Cough & Phlegm & $\begin{array}{c}\text { Persistent } \\
\text { cough and } \\
\text { phlegm }\end{array}$ & Wheeze & Cough & Phlegm & $\begin{array}{c}\text { Persistent } \\
\text { cough and } \\
\text { phlegm }\end{array}$ & Wheeze \\
\hline Rural England" & 25 & & & 29 & 8 & & & 27 \\
\hline Industrial England ${ }^{\star}$ & & & & & & & & \\
\hline Leigh" & 30 & 33 & 18 & 38 & & & & \\
\hline Rhondda' & 42 & 35 & 29. & & 16 & 16 & 10 & \\
\hline Rural Denmark ${ }^{13}$ & 17 & 11 & 10 & 15 & & & & \\
\hline Present study & 27 & 27 & 21 & 34 & 15 & 12 & 9 & 21 \\
\hline
\end{tabular}

*Non-miners detailed questionnaire and lung function tests to be made. Symptoms at screening were no different for those who did and did not attend for detailed assessment, and the ages of the groups were similar. Therefore it is unlikely that any major response bias occurred.

Comparison of our findings with those of earlier surveys that used the same methods is important but difficult because of differences in location and sociodemographic and smoking characteristics. Even so, the prevalence of symptoms has changed little since the 1950s. Table VII compares the findings of studies in rural communities ${ }^{10}$ and among non-miners ${ }^{1112}$ in Britain and in rural communities in Denmark ${ }^{13}$ with those of our study.

Our findings support the clinical impression that the severity of chronic respiratory symptoms is diminishing with time.$^{20}$ The national study of chronic bronchitis carried out by the (Royal) College of General Practitioners in 1961 found that the prevalence of defined chronic bronchitis plus breathlessness on walking on the level was $8 \%$ in men and $3 \%$ in women aged 40-65. The same criteria applied to our study population give a prevalence of $4 \cdot 6 \%$ (a $43 \%$ reduction) in men and $2.5 \%$ (a $17 \%$ reduction) in women aged 40-70. This decrease may be due to reductions in those factors that influence the rate of progression of disease, such as air pollution, treatment for exacerbations due to infection, wider use of inhaled bronchodilators, immunisation against influenza, and reduced smoking. The greater fall in disabling chronic bronchitis among men than among women parallels the relative shift in smoking between the sexes over this time. In 1961 the national survey showed that $7 \%$ of men and $56 \%$ of women were non-smokers, whereas in $1984,64 \%$ of men and $68 \%$ of women were non-smokers. ${ }^{21}$

The diagnostic label of asthma was more prevalent in our study than in earlier studies. In London in 1959, $1 \cdot 8 \%$ of men aged $40-49$ and $0 \cdot 7 \%$ aged $50-59$ said that they suffered with asthma, ${ }^{22}$ whereas in our study $2 \cdot 7 \%$ and $5.0 \%$ of men in these age groups said that they had asthma. On the other hand, the label of chronic bronchitis is less popular: using similar criteria to those of the 1961 national survey we found that general practitioners were now four times less likely to give the label of chronic bronchitis than 24 years previously.

Our study confirms the American finding that the acquisition of a diagnostic label by adult patients with respiratory symptoms depends on factors other than the clinical features. ${ }^{8}$ Patients diagnosed as having asthma were similar in clinical, physiological, and service utilisation indices to those diagnosed as having chronic bronchitis. Social class was the most important predictor of the label of asthma. Though this association has been documented in some studies of asthma in children, ${ }^{23}$ this is the first time it has been described in adults. Difficulty in distinguishing between asthma and chronic bronchitis in adults has been reported in studies based in general practice and hospitals. For example, Wardman et al found that differentiation was not possible in a third of cases in general practice, ${ }^{24}$ and Bucknall et al suggested that general physicians were more likely than respiratory physicians to label a wheezing patient as having chronic obstructive airways disease.$^{25}$ In contrast, Burr et al concluded that asthma and chronic bronchitis could be differentiated. ${ }^{26}$ The mean age of their sample was, however, just over 30 so that the deterioration of lung function suffered by long term asthmatics, ${ }^{27}$ which is the major cause of the diagnostic difficulty, was not yet apparent; indeed, the degree of airways reversibility shown in asthmatic patients was no different from that of those with chronic bronchitis. This confusion in diagnosis was highlighted by Markowe et al, who assessed the prognosis of asthmatics diagnosed in the national 
morbidity survey and found that more deaths were assigned to chronic bronchitis and chronic obstructive airways disease than to asthma. ${ }^{28}$

For every patient with a diagnosis of chronic bronchitis we found another two unlabelled patients with similar symptoms, and for every patient with the diagnosis of asthma we found two or three with wheeze and no diagnosis. This proportion of undiagnosed asthma has also been shown in children..$^{29} 30$ Moreover, if the threshold for the diagnosis of asthma was lowered to include any patients who had suffered an episode of wheezing in the past 12 months then up to a third of this population would be eligible for the label of asthma. This large reservoir of patients suggests that substantial shifts in "asthmatic" patients' rates of using hospitals and general practitioners could easily result from changes in diagnostic fashion alone.

The apparent lack of criteria on which the diagnosis of chronic bronchitis can be distinguished from asthma in adults together with the shift away from the label of chronic bronchitis suggests that a diagnostic transfer from chronic bronchitis to asthma has occurred. The increasing morbidity and mortality that is attributed to chronic obstructive airways disease also suggests that a new diagnostic fashion is emerging. ${ }^{6}$ Until we have universally agreed clinical and epidemiological diagnoses for asthma, chronic bronchitis, and chronic obstructive airways disease we should be cautious in postulating changes in the epidemiology of respiratory disease only on the basis of trends in drug prescriptions and service utilisation statistics. ${ }^{31} 32$

We thank Drs Pollock, Forrester, and Terrell for access to their patients and the secretarial staff of the practice for organising the patients' visits. The terbutaline and Nebuhalers were provided by Astra Pharmaceuticals.

\footnotetext{
1 Anderson HR. Increase in hospitalisation for childhood asthma. Arch Dis Child 1978;53:295-300

2 Office of Population Censuses and Surveys, Royal College of General Practitioners, Department of Health and Social Security. Morbidity statistics from general practice. Third national study 1981-82. London: HMSO, 1986. (Series MB5 No 1.)

3 Burney PGJ. Asthma mortality in England and Wales: evidence for a further increase, 1974-84. Lancet 1986;ii:323-6.

4 Alderson M. Trends in morbidity and mortality from asthma. Population Trends 1987;49:18-23.
}

5 Department of Health and Social Security, Office of Population Censuses and Surveys. Hospital in-patient enquiry. London: HMSO, 1978-86. (Seric $\mathrm{MB} 4,2,3,5,7,10,12,14,16,18,21,23,25$

6 Office of Population Censuses and Surveys. Mortality statistics: cause. London HMSO, 1974-84. (Series DH2, No 1-12.)

Anderson HR. Is the prevalence of asthma changing? Arch Dis Child $1989 ; 64: 172-5$

8 Burrows B, Niden AH, Barclay WR, Kasik JE. Chronic obstructive lung disease. Clinical and physiological findings in 175 patients and their relationship to age and sex. Am Rev Respir Dis 1965;91:521.

9 Dodge R, Cline MG, Burrows B. Comparisons of asthma and chronic bronchitis diagnoses in a general adult population. Am Rev Respir Dis 1986:133:981-6.

10 Higgins ITT. Respiratory symptoms, bronchitis, and ventilatory capacity in random sample of an agricultural population. Br Med 7 1957;ii:1198-203.

11 Higgins ITT, Oldham PD, Cochrane AL, Gibson JC. Respiratory symptoms and pulmonary disability in an industrial town: survey of a random sample of the population. Br Med F 1956;i:904-9.

12 Higgins ITT, Cochrane AL. Chronic respiratory disease in a random sample of men and women in the Rhondda Fach in 1958. Br f Ind Med 1961;18:93.

13 Olsen HC, Gilson G. Respiratory symptoms, bronchitis and ventilator capacity in men. Br.Med f 1960;i:450.

14 College of General Practitioners, Respiratory Diseases Study Group. Chronic bronchitis in Great Britain. Br Med f 1961;ii:973-9.

15 Williams BT, Nicholl JP. Prevalence of hypoxaemic chronic obstructive lung disease with reference to long term therapy. Lancet 1985;ii:369-72.

16 Medical Research Council. Definition and classification of chronic bronchitis for clinical and epidemiological purposes. Lancet 1965;i:775-9.

17 Cotes JE. Lung function: assessment and application in medicine. Oxford: Blackwell Scientific, 1975 .

8 Office of Population Censuses and Survers. Classification of occupations. London: HMSO, 1980.

19 College Committee on Thoracic Medicine. Disabling chest disease: prevention and care. $\mathcal{F} R$ Coll Physicians Lond 1981;15:69-87.

20 Littlejohns P, Williams ES. Job loss and family morbidity. I R Coll Gen Pract 1986;36:176.

21 Office of Population Censuses and Surveys. General household survey 1985 London: HMSO, 1987. (Series GHS No 14.)

22 Holland WW, Reid DD. The urban factor in chronic bronchitis. Lancet $1965 ;$ i: $445-8$.

23 Peckham C, Butler N. A national study of asthma in childhood. 7 kipidemiol Community Health 1978;32:79-85.

24 Wardman AG, Binns V, Clayden AD, Cooke NJ. The diagnosis and treatment of adults with obstructive airways disease in general practice. $\mathrm{Br} \mathcal{J}$ Dis Chest $1986 ; 80: 19-26$.

25 Bucknall CE, Robertson C, 'Moran F, Stevenson RD. Differences in hospital asthma management. Lancet 1988; ; 748 -50.

26 Burr ML, St Leger ST, Bevan C, Merrett TG. A community survey of asthmatic characteristics. Thorax 1975;30:663-8.

27 Brown PJ, Greville HW, Finucane KE. Asthma and irreversible obstruction. Thorax 1984;39:131-6.

28 Markowe HLJ, Bulpitt CJ, Shipley MJ, Rose G, Crombie DL, Fleming DM. Prognosis in adult asthma: a national study. Br Med f 1987;295:949-52.

29 Anderson HR, Bailey PA, Cooper JS, Palmer JC. Influence of morbidity, illness label, social, family and health service factors on drug treatment of childhood asthma. Lancet 1981;ii: 1030-2.

30 Speight ANP, Lee DA, Hey EN. Underdiagnosis and treatment of asthma in childhood. Br Med f 1983;286:1253-8.

31 Fleming DM, Crombie DL. Prevalence of asthma and hay fever in England and Wales. Br Med f 1987;294:279-83.

32 Hay IFC, Higenbottom TW. Has the management of asthma improved? Lancet 1987;ii:609-10.

(Accepted 22 March 1984
Department of Child

Health, Medical School, University of Newcastle upon Tyne, Newcastle upon Tyne NE2 4HH

$\mathrm{R}$ Skinner, MRCP, honorary research associate

A D J Pearson, MRCP, lecturer

in paediatric oncology

L Price, RSCN, research sister

K Cunningham, MRCP,

Leukaemia Research Fund

training fellow

A W Craft, FRCP, director of

paediatric oncology

Correspondence to:

Dr Skinner.

BrMed f 1989;298:1560-1

\section{Hypophosphataemic rickets after ifosfamide treatment in children}

\author{
R Skinner, A D J Pearson, L Price, \\ $\mathrm{K}$ Cunningham, A W Craft
}

Ifosfamide is being increasingly used to treat solid tumours in children. Adverse effects include nausea, vomiting, alopecia, myelosuppression, and haemorrhagic cystitis. Nephrotoxicity has been reported in adults, with both glomerular disease! and tubular damage, which led to Fanconi's syndrome in two patients. ${ }^{23}$ Studies in children, however, have not found any appreciable nephrotoxicity. ${ }^{+}$We describe three children with previously normal renal function and bone biochemistry who developed hypophosphataemic rickets due to urinary loss of phosphate after high dose ifosfamide treatment for malignancy.

\section{Case reports}

Case 1-A 23 month old boy with embryonal rhabdomyosarcoma of the prostate received local radiotherapy and chemotherapy over 18 months. The chemotherapy comprised ifosfamide (total dose $\left.177 \mathrm{~g} / \mathrm{m}^{2}\right)$, cisplatin $\left(90 \mathrm{mg} / \mathrm{m}^{2}\right.$ per course with mannitol and hydration, total dose $359 \mathrm{mg} / \mathrm{m}^{2}$ ), cyclophosphamide, vincristine, adriamycin, actinomycin $\mathrm{D}$, and etoposide. He remained well with no evidence of recurrence of the tumour, but nine months after chemotherapy ended he developed difficulty in walking due to knock knees. Radiographs of his knees showed signs of rickets and secondary hyperparathyroidism. Further investigations showed a low glomerular filtration rate and renal tubular damage, with an adult type Fanconi's syndrome, comprising hypokalaemia, phosphaturia, hypophosphataemia, glycosuria, acidosis, and impaired urinary acidification and concentration (table). Serum alkaline phosphatase activity was raised. After treatment with oral phosphate his serum phosphate concentration rose to normal and his gait improved.

Case 2-A 4 year old girl with embryonal rhabdomyosarcoma of the left middle ear received radiotherapy and chemotherapy consisting of ifosfamide (total dose $132 \mathrm{~g} / \mathrm{m}^{2}$ ), actinomycin $\mathrm{D}$, adriamycin, vincristine, and etoposide. After receiving ifosfamide for eight months $\left(108 \mathrm{~g} / \mathrm{m}^{2}\right)$ she developed a painful limp; investigation showed hypophosphataemia, phosphaturia, glycosuria, and raised serum alkaline 